\title{
Probing the Potential of Community-Based Transportation Facilities: A Case of Community Managed School Van Service in Dhaka City
}

\author{
Anutosh Das ${ }^{1,2}$, Sharmin Akter ${ }^{1}$, Sumita Roy ${ }^{1}$, Mohammad Shahriyar Parvez ${ }^{1}$
}

${ }^{1}$ Department of Urban \& Regional Planning, Rajshahi University of Engineering \& Technology, RUET, Rajshahi-6204, Bangladesh.

${ }^{2}$ Department of Urban Planning and Design, The University of Hong Kong (HKU).

\begin{abstract}
:
Social safety, security, and comfort of school-going children during the travel time to school becomes a subject of anxiety to the parents and is a crucial issue in recent times. In this regard, community-based transport can be a significant way to address social security issues in travel at a reasonable cost and reduce the burden on private mode. In Dhaka city, school van service already exists but due to some sort of problems the service has not been proved an efficient and formal mode of transport for solving mobility problems. This study seeks to identify the existing problems and prospects of the school van service and provide a unique, healthy, safe, and reliable transport mode for children. Applying different tools of the Participatory Rural Appraisal (PRA) method, the problems and solutions have been drawn from the community. The recommendations of this study will help the school van services (a community-managed para-transit system) to be more functional in playing a vital role in solving the problems of short-distance travel. This service has great potentialities to be adopted in other trips such as trips to and from offices which will lessen the road congestion at the peak periods.
\end{abstract}

Keywords: Community-Based Transportation, Para-Transit, School Going Children, Social Security, Participatory Rural Appraisal.

\section{Introduction:}

While a poor transportation system poses a severe risk to environmental sustainability along with 
a severe threat to economic viability, a well-planned and active urban transport system is one of the crucial issues for city development (Khan \& Mahmud, 2012). Apart from the whole country's transport structure, every community demands a safe and secure transport system different from the conventional transport system ensuring function, safety, and comfort to the respective neighborhood characteristics (Zwart \& Welsby, 2006)(Sara, 2019). In this respect, the communitymanaged transportation system has been identified as one of the most effective tools for fulfilling the requirements of the community people (Sharmeen \& Israt, 2013) (Kobra, Kabir, \& Biswas, 2020). It also meets the safe transport demand of society's lower- and middle-income groups and enhances job opportunities (Zaman, 2019).

Dhaka is the only one and the fastest-growing megacity of Bangladesh, which is already standing with inadequate transport infrastructure facilities (Zaman, 2019). The main reason for this increasing population and inadequate facilities is Mass migration from the suburban area where $83.5 \%$ of the men migrated along with their families for better living, education, and job facilities (Biswas, Kabir, \& Khan, 2019). However, the immense traffic problem makes the existing transport system unsuitable and unsafe for daily users. Thousands of students face numerous hurdles while traveling to school and returning (The Independent, 2018). Besides, reckless driving often causes many tragic accidents and deaths of school-going children (Sharmeen \& Israt, 2013). Consequently, most parents are bound to bring their children to school using a private vehicle like a private car, motorbike, or other means of non-motorized transports like rickshaw, van, etc. (Daily Sun, 2021). In this way, they contribute a lot to the existing traffic congestion problem in Dhaka city, especially during the opening and closing times of the school. A community-based transportation system may prove helpful in resolving this problem to some extent (Kobra, Kabir, \& Biswas, 2020)

There are numerous educational institutions in Dhaka city, but only a few public modes of transport are available exclusively for children (The Independent, 2018). As a result, students have to suffer for a longer time period due to traffic jams or inefficient transport facilities. Because of traffic jams, students lose their energy rather than because of their studies (Khaled, 2020). To resolve this problem, Various types of community-based transport facilities already exist in different cities and countries in the world (MTC, 2021) (Zwart \& Welsby, 2006). However, in Bangladesh, examples of such facilities are pretty familiar. Community-based school van service in Dhaka city falls within this category. This school van service provides transportation to and from school for school children. Only schoolchildren are transported by this service, which provides some degree of security. However, in our country, where the majority of people cannot afford school buses or micro-bus services for carrying their children to school, this current school van service offers enormous potential. Though these services are quite old, it has not been established as a formal mode of transport in our country and Dhaka city. Again, from a financial perspective, it is quite cost-effective than other modes of transport. 
Nevertheless, due to the lack of proper research and concentration of the responsible authority, this practice remains overlooked that badly affects the present service quality of the community transport system. Besides, only a few researches can be found addressing these services; however, these also merely ensure active participation of the community people and the service holders. So, this study focuses on identifying operational processes, problems, and solutions to present community school transport services. This study also focuses on identifying prospects of this service to observe the system's sustainability issue. In the whole research process, the active participation of community people and service holders has been ensured to make the research more reliable and to get the best output.

\section{Literature review:}

\subsection{Concept of community-based transport service:}

Some individuals or groups from every community need a unique transport system where conventional transport systems like private vehicles, taxis, and commercial buses are not suitable or available (Zwart \& Welsby, 2006). Besides, communities with no well-connected and flexible transport system often suffer a lot. Here, community transport operators nearby can offer a solution for those essential journeys (Boston, 2018). In the case of older people, community transport is vital in enabling them to remain active in community activity and treat them as valuable people of society (MTC, 2021). Community-based transport facilities can also meet the transport needs of community peoples of all ages by providing easy access to educational, shopping, medical, and other social facilities without suffering from traffic jams or other public transport hassles.

Moreover, this facility has the potential of transforming our boring journey time into a space for social interaction (Zwart \& Welsby, 2006). These types of transport reduce the fear of crime, provide special facilities to the physically disabled person, provide easy accessibility to the people of the remote area through providing door-to-door services. The success of this community transport system is mainly dependent on community engagement and the external environment (Kotecha, Davies, Miscampbell, Barnard, \& Hughes, 2017). Besides bringing local residences, community organizations, and transportation agencies together, it helps to identify community transportation challenges and develop strategies to overcome them (MTC, 2021).

\subsection{Present school transport system in Dhaka city}

A deficient public transportation system, private institutions, and lack of investment create substantial and multifaceted challenges in Bangladesh (Hossain, 2018). One of the worst-hit areas in Dhaka city. When this condition affects school-age children, it warrants immediate attention. In Dhaka, the use of public transportation is prevalent. Thousands of students cannot go to class on time because of transportation problems, i.e., traffic jams (The Independent, 2018). Although most of the transports are owned by the institutional authority (University, school, and school), most college and university students are mature enough to travel to their educational institutions by themselves. In case of traveling via school/ university buses, they have to pay a certain amount 
monthly or over the year. In some pre-elementary schools, two types of transport services can be found, i.e., transport directly provided by the school authority or hiring transport by the community to travel their children to school. The second one is a prevalent practice of Dhaka city, especially for lower- and middle-income groups of people. Although many problems arise every day regarding school transport service, due to lack of proper knowledge, research, and policy this issue always remains in the darkness.

\subsection{Importance and Application of Participatory approaches for solving community problems}

Measuring the efficiency of any operational service is one of the predominant characteristics of system sustainability. Furthermore, in the 21 st century, measuring, monitoring, and improving efficiency are the main tasks for any system analysis (Chambers, 1994). In that case, Participatory Rural Appraisal (PRA) can be one of the most effective tools to measure the efficiency of community transport services (Chambers, 1994). PRA can easily concern the behavior and attitude of outsider facilitators, not rushing, and being critically self-aware. In PRA, there is also an emphasis on empowering local peoples where the local peoples play an important role through active participation through drawing up plans and problems (Bharat Sontakki, 2019). Apart from these, PRA is a time and cost-effective approach that encourages the researchers to collect and analyze data from past and present events and future approaches. Moreover, all of this helps to get a comprehensive idea regarding the plan, community problems, present $\&$ possible constraints, and prospects (Chandra, 2010). And this participatory process helps to create a linkage between survival strategy, knowledge system, and sustainable living as well (Chandra, 2010) (Abrol \& Gupta, 2015)

\section{Research Methodology \& Data}

\subsection{Study area profile:}

Two residential colonies of Dhaka city, namely Nilkhet South Staff Colony and Nilkhet BCS Staff Quarter, have been selected as the study area. Nilkhet South Staff Colony is situated under word no. 21 of Dhaka South City Corporation. It is situated between Dhaka University and Home Economics College. Nilkhet BCS Staff Quarter is situated under word no. 18, New Market Thana. It is situated beside Gausul Azam market (Dhaka south city corporation, 2014). Nilkhet Staff colony consists of two different parts. The southern part is for teachers of Dhaka University, and the northern part is for fourth class employees of Dhaka University. It has 52 buildings, each of which is about five stories. Every floor has two units. The average household size is six. Nilkhet BCS Staff Quarter has ten buildings which are six storied. Each building has two dwelling units. The study area's total population (both colonies) is around 4464. The number of school-going children is around 150. About fifty students use the school van service (Field survey, 2015).

\subsection{Data collection and Analysis:}

The data collection procedure at this study fully utilized Participatory Approach. Both 'Time Related PRA Method' and 'Space Related PRA Method were used to depict the existing scenario 
of the study area. Social Mapping, Resource Mapping, Mobility Mapping, Route Mapping have been used as space-related PRA tools to analyze the spatial dimension of the society. Time Related PRA method used Timeline of the community, Timeline of van service in the community, Seasonal Diagram of both school-going children and van driver, Daily Activity Scheduling of both schoolgoing children and Van diver, etc. Process Map showed the process of van service operation. Cause effect diagram and Force Field Analysis identified the major problems, driving forces, and restraining forces of the successfulness of community van service. Focus group discussion and participatory, interactive group discussion between the community people and van drivers' community was arranged to find some vetting solutions to the existing problems. The facilitators gave additional solutions and suggestions based on the study findings and discussion.

\section{Historical Background}

\subsection{Historical background of the community}

In between Nilkhet South Staff colony and BCS staff Quarter vicissitudes development trend (in between 1947-1985) can be noticed for Nilkhet colony (Table 01). Apart from the gradual development of the community, the scary impact of the liberation war was also narrated by the community people. But the staff quarter is relatively newly constructed, and still, no record of harmful incidents hampering the community development was found.

Table 01: Historical trend of community establishment and development

\begin{tabular}{|c|c|c|c|}
\hline \multicolumn{2}{|c|}{ Nilkhet South Staff colony } & \multicolumn{2}{|c|}{ Nilkhet BCS Staff Quarter } \\
\hline Year & Activities & Year & Activities \\
\hline 1947 & Established as a semi-permanent tin sheds buildings & 2000 & $\begin{array}{l}\text { Construction of the building was } \\
\text { completed and people started living. }\end{array}$ \\
\hline 1951 & Improved to permanent three-storied buildings & & $\begin{array}{l}\text { One of the four buildings was allocated } \\
\text { for BCS cadres. }\end{array}$ \\
\hline 1967 & $\begin{array}{l}\text { An employee union and clubhouse for a fourth-class } \\
\text { employee had been established }\end{array}$ & & $\begin{array}{l}\text { A community organization evolved to } \\
\text { solve the local matter. }\end{array}$ \\
\hline 1971 & $\begin{array}{l}\text { A large number of buildings in this area were } \\
\text { devastated because of the liberation war }\end{array}$ & 2003 & new four buildings established. \\
\hline 1979 & $\begin{array}{l}\text { Existing buildings improved to } 5 \text { storied residential } \\
\text { building }\end{array}$ & 2007 & $\begin{array}{l}\text { previous three storied buildings were } \\
\text { improved to } 5 \text { or } 6 \text { storied buildings. }\end{array}$ \\
\hline 1980 & $\begin{array}{l}\text { The internal mud road within the community improved } \\
\text { to gravel roads. And a mosque was established. }\end{array}$ & 2012 & $\begin{array}{l}\text { another three buildings were established } \\
\text { for BCS cadre }\end{array}$ \\
\hline 1985 & $\begin{array}{l}\text { A tower building of } 6 \text { stories was established in this } \\
\text { community. }\end{array}$ & 2013 & $\begin{array}{l}\text { a separate building established for Jessore } \\
\text { society. }\end{array}$ \\
\hline
\end{tabular}

(Source: Field Survey, 2015) 


\subsection{Historical background of school van service:}

For attaining the historical background of school van service Mr. Shukur Mia, one of the oldest van service providers, acted as a key informant. Other van service providers also provided information about the advancement of the school van service. In the beginning, Mr. Shukur Mia started working as a van driver at Motijheel Ideal school in 1995. He worked there for five years. Due to a considerably low salary, he left the job. After that, he started his own business of school van service named "Sharmeen Paribahan" in the study area for the last fifteen years. He has almost 12 vans on different routes. Now, he also pulls the school van for Udayan school-going children. He collects students from Tannery Mor, Jigatola, Dhanmondi 15, Central Road, Bhuter Goli, Kathal Bagan, Hatirpul, Elephant Road, Katabon. In 2009 van fare increased due to inflation. However, the monthly payment rate (van fare) varies according to the collection place. The availability of students fixes the route. There were very few students because of less awareness among the people about the service. They also did not have much trust in this type of service. Now, this type of service is well known throughout Dhaka city. So now there are enough students for him to collect. Gradually he also built his trust among the community people. To ensure a trusted environment among the parents and other community people, he gives them a copy of his national ID card, license, and other relevant documents when he agrees with the guardian of students. He mainly transports the children from middle-income groups.

\subsection{Resource inventory:}

Resource inventory of Nilkhet South Staff colony: Quarters at Nilkhet South Staff colony are provided by the authority of Dhaka University. Besides, most of the utility and community facilities are provided by the Dhaka South City Corporation. The streets and the plots are laid out in a gridiron pattern within the locality. The area is planned where all utility, community and social facilities are available. This locality's utility and community facilities include two playgrounds, five corner shops, one clubhouse, one community co-operative society, two mosques, one garage, etc. There also exists an informal community co-operative society in this locality. This society is constituted of the aged male persons of the community. They are engaged in solving different conflict resolution and many other problems within the community. Most of the buildings within this locality are five to six storied. The northern portion of the area is allocated to the teachers of Dhaka University. The residence of the middle- and the lower-income group is in the southern portion of the area. Residents are mainly fourth-class employees of Dhaka University. They were renting their flat fully or as a sublet is one of the major sources of income of this community people. The area has no school. Around $30 \%$ of the students use the school van service. Most of the students of this community use school vans to go to Agrony and Rayhan School in the Aimpur and Udayan School in the Dhaka University area.

Resource inventory of Nilkhet BCS staff quarter: All of the facilities at the BCS staff quarter are almost similar to the Nilkhet South Staff colony. The authority of Dhaka University provides buildings of the BCS staff quarter colony, and most of the utility and community facilities are 
provided by the Dhaka South City Corporation. This locality's utility and community facilities include one playground, six corner shops, one clubhouse, one community co-operative society, one mosque, etc. Several restaurants along the roads (in front of the Gausul Azam market) in the southern portion of this community create a vibrant community space in this area (Figure 01). The government employees mainly use the clubhouse. The members of the co-operative organization are engaged in solving different conflict resolution and many other problems within the community. Most of the buildings within this locality are five to six storied. Only three buildings of this community (each six storied) are allotted to the BCS Cadres. As the authority of Dhaka University provides the quarters, most of the utility and community facilities are provided by the Dhaka south city corporation. Both people of high- and middle-income groups live in this community. About sixty to seventy percent of students of this community use school vans to go to school. Most of the students of this community use van service to go to Agrony School in the Aimpur and Udayan School in the Dhaka University area.
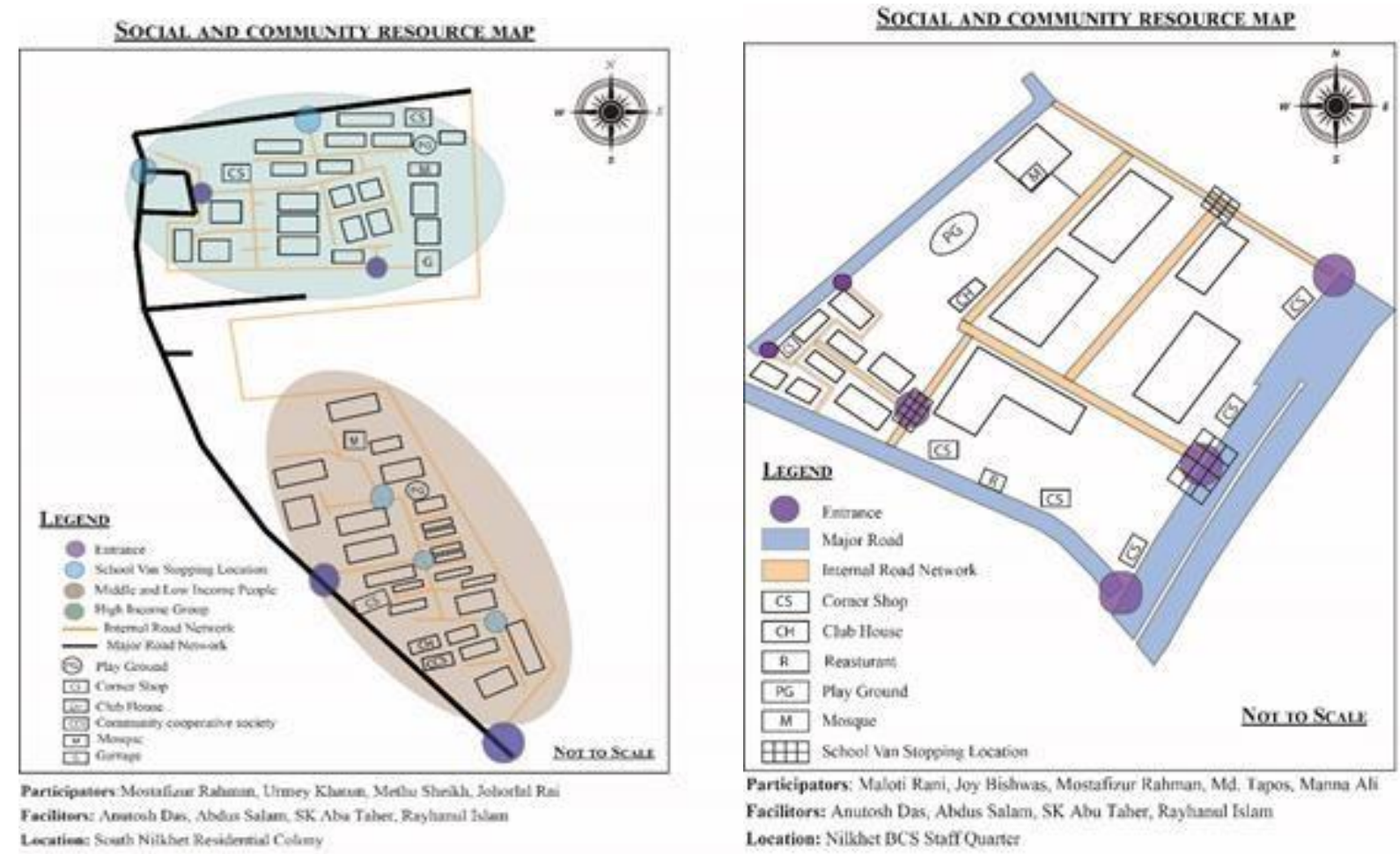

Figure 01: Social and community Resource Map of South Nilkhet Residential Colony (left) and Nilkhet BCS staff Colony (Right) 


\section{Analysis and Discussion}

\subsection{Operating procedure of van service}

Route Map: The journey of the school van starts from the Jigatola Mor. Route diversion starts from the Bata Signal Mor and moves through Bata signal, Katabon, BCS staff quarter, and South Nilkhet Residential colony for collecting students on the way to Udayan school. The van driver also starts their journey from Jigatola and moves through Bata signal, through Gausia, Mirpur road, and after collecting students from both the community, they reach Rayhan school and Viqarunnessa school and college. In the route map, black represents the van route traveling to the Rayhan school and Viqarunnessa school and college. In Figure 02, the green one represents the van route traveling to the Udayan school. The school van crosses some major intersections on the way to the school, which is also one of the reasons for the slow movement of the vehicle. After closing school, the van drivers take the students back to their homes, following the same route.

\section{ROUTE MAP OF SCHOOL VAN SERVICE}

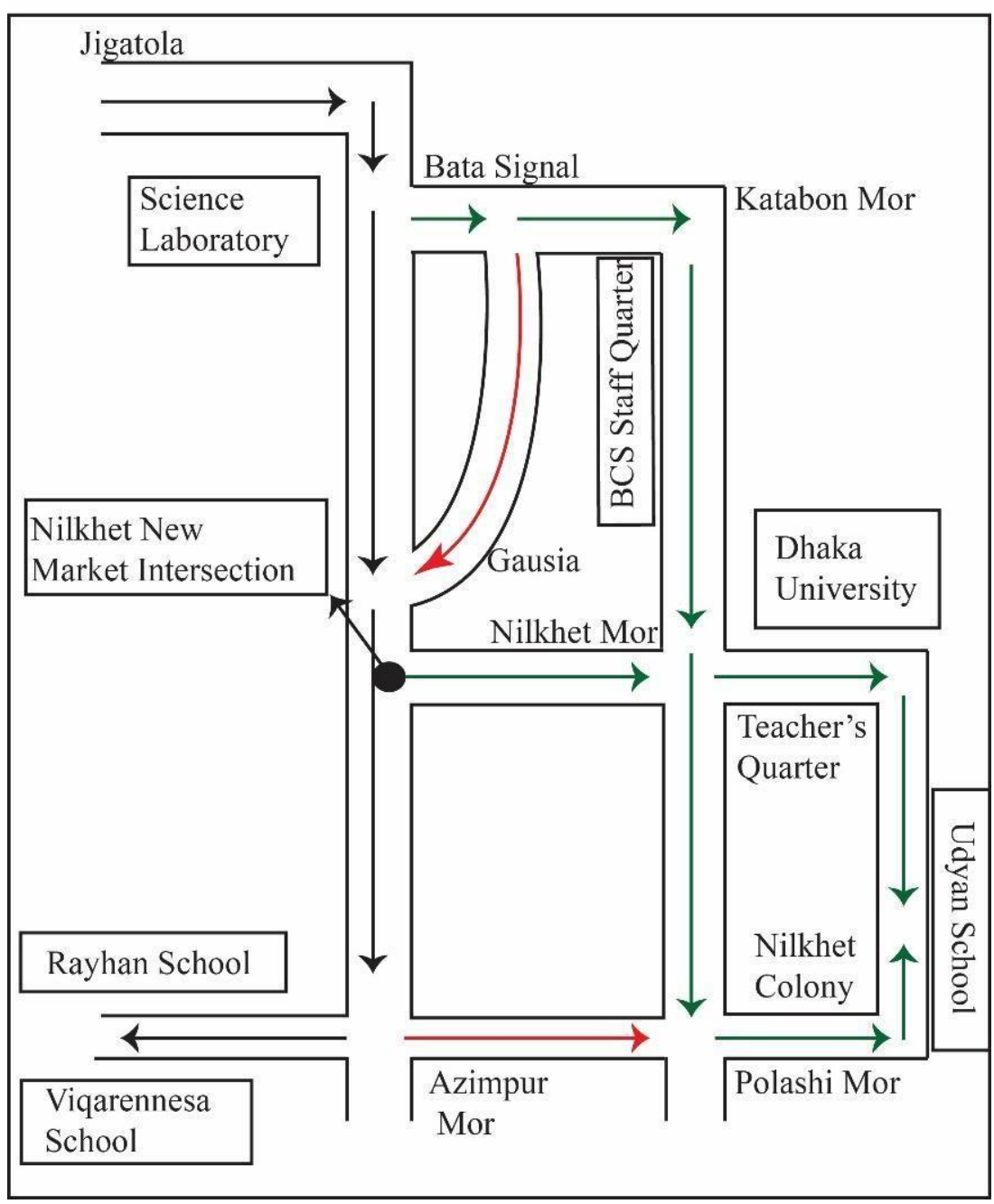

Figure 02: Route Map of School Van Service

(Source: Field Survey, 2015) 
Process Map: The hiring procedure on van service follows a well-developed process by the residences. At first, guardians collect the service provider's contact information from other parents who use it or from the school office. After that, the guardian contacts the van owner or "Van malik Kallyan Samiti" through the van driver. Consequently, parents give the address to the service provider for an agreement. The Van owner comes to the parent's house to meet and makes the final agreement. The Van owner gives them the photocopy of his national ID card, license, and other legal documents along with his number for emergency contact of van driver for trust-building. The van owner typically appoints a van puller of the nearby locality listed in the "Van malik Kallyan Samiti." Van driver collects the students and drops them at school in the morning. After school, he drops the children at the specific stoppage point. Then parents receive their children and bring them back to the house. The process is shown in Figure 03.

\section{PROCESS MAP OF SCHOOL VAN OPERATION}

Parents collect the information about the service from other parents who use it. First, they collect contact number of the van service provider.

Parents call the service provider or van driver, made initial agreement over the phone.

Parents give the address to the van driver.

Then the van driver comes to the house to meet the parents and makes the final agreement.

Van driver gives them the photocopy of his national ID card, license and other legal documents for trust building. He also gives his phone number for emergency contact.

Van driver mainly collects children from adjacent road of the community.

Van driver collects the students and drop them at school in the morning. After the school, he drops them at their stoppage point.

Parents receive their children and bring back to the house.

Figure 03: Community Van service Hiring Procedure 


\subsection{Mobility pattern of the community people:}

The community people at south Nilkhet residential colony primarily work at Dhaka University The community people of BCS staff quarter are mainly government workers. So, the Nilkhet community needs frequent visits to the Dhaka University area, and other communities regularly need to go to Gulistan and Agargaon for working purposes. Bus, office bus and the private car is the most frequent mode used by BCS staff quarter people. On the other hand, people of the south Nilkhet residential colony used to travel by rickshaw or by foot to go to their offices or other places. As most of the coaching centers are in Azimpur, so female members of the family daily visit Azimpur to carry their children to the coaching center. They mainly use rickshaws for traveling to the coaching center. Community people travel to the new market regularly to buy their daily accessories and shopping purposes. The female member of the BCS quarter visits the Basundhara city complex mainly once a week for shopping purposes. They mainly use their private car or rickshaw for these cases. In the afternoon, both male and female members take a walk to the adjacent park for refreshment. For taking medical services in both communities, people go to the nearby Dhaka medical college. They also travel Lalbagh Fort and other historical places in old Dhaka for recreational purposes. For these cases, they mainly use rickshaws or buses for this purpose. Figure 04 illustrates the mobility of the community people.

\section{MOBILITY PATTERN OF THE COMMUNITY PEOPLE}

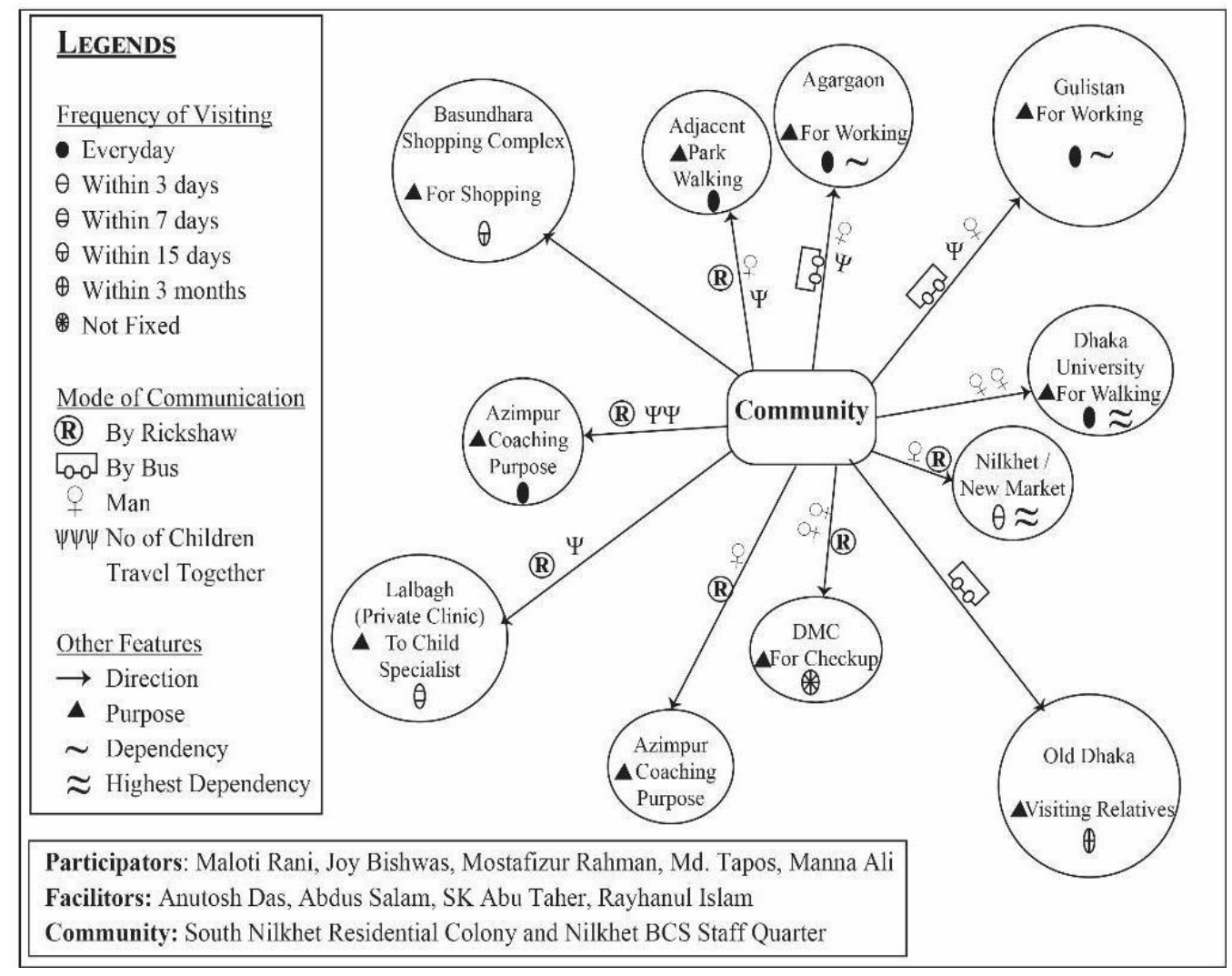

Figure 04: Mobility Pattern of the Community People

(Source: Field Survey, 2015) 


\subsection{Daily Activity Schedule of children and women:}

Most of the school-going children wake up at around 6 AM. They take their breakfast from 6AM to $8 \mathrm{AM}$ and prepare themselves for school. They return from school within $1 \mathrm{PM}$ to $5 \mathrm{PM}$. Those children who have morning school usually return around 1 PM. Other high school-going children who have evening school return around 5 PM. After returning, they take a bath, eat food, and spend some time resting and playing. Some students have coaching classes or tuition. They finish their additional study works besides school within 8 PM usually. After that, they take a rest for about half an hour. They watch television, play video games, listen to music, etc. After that, they go to the study table to prepare the next day's homework for school within 10 PM. Dinner time is around 10 o'clock. Sometimes they watch television at this time. They go to bed from 10.30 PM to 11 PM. Figure 05 shows the daily activity schedule of women and school-going children.

DAILY ACTIVITY SCHEDULE OF WOMENS AND SCHOOL GOING CHILDRENS

\begin{tabular}{|c|c|c|c|c|c|c|c|c|}
\hline $\begin{array}{c}\text { TIME } \\
\text { SCHEDULE }\end{array}$ & 6:00am- & 3:00am- & - & 5:00pm- & $\begin{array}{l}8: 00 \mathrm{pm}- \\
8: 30 \mathrm{pm}\end{array}$ & $\underbrace{10: 00 \mathrm{pm}}_{8: 30 \mathrm{pm}-}$ & $\begin{array}{c}10: 00 \mathrm{pm}- \\
10: 30 \mathrm{pm}\end{array}$ & 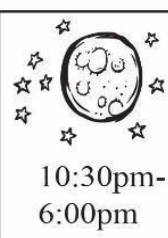 \\
\hline $\begin{array}{l}\text { CHILDRENS } \\
\text { ACTIVITIES }\end{array}$ & $\begin{array}{l}\text { Preparing } \\
\text { for school }\end{array}$ & At school & $\begin{array}{l}\text { Bathing, } \\
\text { lunch, } \\
\text { entertain } \\
\text { ment } \\
\text { (playing } \\
\text { games) }\end{array}$ & Coaching & Taking rest & $\begin{array}{l}\text { Completing } \\
\text { Home } \\
\text { works }\end{array}$ & $\begin{array}{l}\text { Taking } \\
\text { Dinner } \\
\text { and } \\
\text { watching } \\
\text { TV }\end{array}$ & $\begin{array}{l}\text { Going to } \\
\text { Sleep }\end{array}$ \\
\hline $\begin{array}{l}\text { WOMENS } \\
\text { ACTIVITIES }\end{array}$ & $\begin{array}{l}\text { Raising, } \\
\text { preparing } \\
\text { and carrying } \\
\text { childrens to } \\
\text { the school } \\
\text { van }\end{array}$ & $\begin{array}{l}\text { Cleaning } \\
\text { and washing } \\
\text { clothes, } \\
\text { cooking }\end{array}$ & $\begin{array}{l}\text { Taking care } \\
\text { of the } \\
\text { childrens, } \\
\text { eating lunch } \\
\text { resting \& } \\
\text { gossiping. }\end{array}$ & $\begin{array}{l}\text { Walking, } \\
\text { gossiping \& } \\
\text { shopping at } \\
\text { weekend. } \\
\text { Preparing } \\
\text { dinner }\end{array}$ & $\begin{array}{l}\text { Preparing } \\
\text { dinner }\end{array}$ & $\begin{array}{l}\text { Helping } \\
\text { childrens } \\
\text { with } \\
\text { homework }\end{array}$ & $\begin{array}{l}\text { Taking } \\
\text { Dinner } \\
\text { and } \\
\text { watching } \\
\text { TV, family } \\
\text { gossiping }\end{array}$ & $\begin{array}{l}\text { Completing } \\
\text { other family } \\
\text { tasks and } \\
\text { going to } \\
\text { bed. }\end{array}$ \\
\hline
\end{tabular}

Participants: Laila Banu, Maloti Rani Biswas, Shipra Sarker, Kulsum Begum

Facilitators: Anutosh Das, Abdus Salam, SK Abu Taher, Rayhanul Islam

Community: South Nilkhet Residential Colony and Nilkhet BCS staff Quarter

Figure 05: Daily Activity Schedule for Women's and School Going Children's

(Source: Field Survey, 2015)

Most women rise very early in the morning and start their day around 6 AM. Because they have to prepare their children for school, make breakfast, prepare a tiffin box for their children, and carry them to the place where the school van stops. After finishing their breakfast, they start daily household works. They spend some time cleaning and washing clothes. They start cooking lunch at around 11 o'clock. Around 1 PM, children come back from school. After receiving the children's and getting back home, they help their children get fresh. After that, they take their Lunch and make a short nap. Around 4 PM, they go outside and sometimes walk in the residential area. They 
do some community gatherings with others women. They use to gossip with each other. On the weekend, they use this time for shopping purposes. Around 7 PM, they start cooking for dinner. Besides cooking they also help their children on preparing home works. Usually, they eat dinner around $10 \mathrm{PM}$. After dinner, they spend some time on family talk and watching television. They go to bed around midnight.

\subsection{Seasonal Diagram of the school van going children:}

Seasonal map of school-going children shows the variation of their activities in a different season of the year. Firstly, school van payment varies from time to time in a year. In April, May, and December, the van driver was payees without the service of the van because, at that time, the school was either closed or unable to access due to rain. Students' happiness is also varied throughout the year. In January, it is difficult for the children to go to school in the morning due to cold weather. Maintaining the regular class in May and August is difficult due to high temperatures and heavy rain. In December, after the final exam, the students are free from their studies, that is why those are the happiest month of the year. In January, May, and August, the number of attendances is lower than the other times of the year due to weather. Students used to sleep for a long time in January and December due to cold weather and needed to do less work. The sickness rate among the students is very much high in January, June, July, August, September, and November (Figure 06).

\section{SEASONAL ANALYSIS OF SCHOOL VAN GOING CHILDRENS}

\begin{tabular}{|c|c|c|c|c|c|c|c|c|c|c|c|c|}
\hline Month & 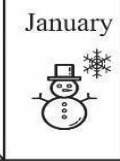 & February & 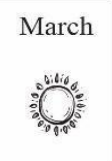 & 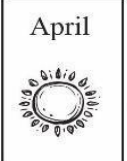 & May & June & July & August & $\frac{\text { September }}{0.000}$ & 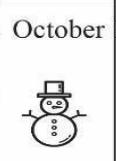 & 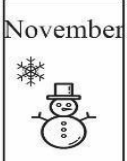 & 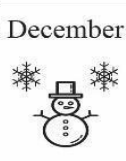 \\
\hline$\frac{\text { School Van }}{\text { Payment }}$ & ॠ秋 & खै & ॠ & $\begin{array}{l}\text { 民 } \\
\text { (Payment } \\
\text { without } \\
\text { van use) }\end{array}$ & 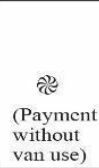 & \& & ॠथ & 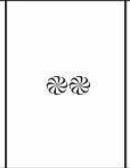 & \# & 稀 & 象眼 & ॠ \\
\hline $\begin{array}{l}\text { Students } \\
\text { Happiness } \\
\text { ФФФФФ } \\
\text { Very High } \\
\Phi \text { Very low }\end{array}$ & \begin{tabular}{|c}
$\Phi \Phi$ \\
(Cold winter \\
morning)
\end{tabular} & ФФФФ & ФФФФ & $\begin{array}{c}\Phi \Phi Ф \Phi \Phi \\
\text { (Vacation) }\end{array}$ & 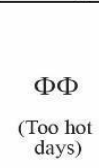 & ФФФФ & $\Phi \Phi$ & $\begin{array}{c}\Phi \Phi \Phi \\
\begin{array}{c}\text { (Too much } \\
\text { rain) }\end{array}\end{array}$ & ФФФ & ФФФФ & ФФФ & ФФФФФ \\
\hline $\begin{array}{l}\frac{\text { Students }}{\text { Attendance }} \\
\text { Q Present } \\
\text { O Absent }\end{array}$ & $\begin{array}{ll}Q & \Theta \\
Q & \Theta \\
Q & Q \\
Q & Q\end{array}$ & $\begin{array}{ll}Q & \Theta \\
Q & \Theta \\
Q & Q \\
Q & Q\end{array}$ & $\begin{array}{ll}Q & \Theta \\
Q & \Theta \\
Q & \Theta \\
Q & Q\end{array}$ & $\begin{array}{ll}\Theta & \theta \\
\Theta & \Theta \\
\Theta & \Theta \\
\varphi & Q\end{array}$ & $\begin{array}{ll}\Theta & \Theta \\
\Theta & \Theta \\
\Theta & \Theta \\
Q & Q\end{array}$ & $\begin{array}{ll}\mathrm{O} & \mathrm{O} \\
\mathrm{Q} & \Theta \\
\mathrm{O} & \mathrm{Q} \\
\mathrm{O} & \mathrm{Q} \\
\mathrm{Q} & \mathrm{Q}\end{array}$ & $\begin{array}{ll} & \Theta \\
& \Theta \\
O & O \\
& O \\
& Q\end{array}$ & $\begin{array}{ll} & \\
Q & \theta \\
O & \theta \\
0 & \theta \\
0 & 0 \\
& 0\end{array}$ & $\begin{array}{ll}Q & \Theta \\
Q & \Theta \\
Q & \Theta \\
Q & \Theta\end{array}$ & $\begin{array}{ll}Q & \Theta \\
Q & \Theta \\
Q & \Theta \\
Q & Q\end{array}$ & $\begin{array}{ll}\mathrm{Q} & \mathrm{Q} \\
\mathrm{Q} & \mathrm{Q} \\
\mathrm{Q} & \mathrm{Q} \\
\mathrm{Q} & \mathrm{Q}\end{array}$ & $\begin{array}{ll}\Theta & \theta \\
\Theta & \theta \\
\Theta & \Theta \\
\Theta & \Theta\end{array}$ \\
\hline Sickness & $\begin{array}{ll}\dot{\phi} & \varnothing \\
\dot{\phi} & \varnothing \\
\dot{\varnothing} & \varnothing \\
\dot{\varnothing} & \varnothing\end{array}$ & $\begin{array}{l}\varnothing \\
\varnothing \\
\varnothing \\
\varnothing \\
\varnothing\end{array}$ & $\begin{array}{l}\dot{\varnothing} \\
\varnothing \\
\varnothing \\
\varnothing \\
\varnothing\end{array}$ & $\begin{array}{l}\dot{\varnothing} \\
\dot{\varnothing} \\
\dot{\varnothing} \\
\dot{\varnothing}\end{array}$ & $\begin{array}{l}\varnothing \dot{~} \\
\varnothing \\
\varnothing\end{array}$ & $\begin{array}{ll}\dot{\varnothing} & \varnothing \\
\dot{\varnothing} & \varnothing \\
\dot{\varnothing} & \varnothing \\
\dot{\varnothing} & \varnothing\end{array}$ & $\begin{array}{ll}\dot{\phi} & \varnothing \\
\dot{\varnothing} & \varnothing \\
\dot{\varnothing} & \varnothing \\
\dot{\varnothing} & \varnothing\end{array}$ & $\begin{array}{ll}\dot{\phi} & \varnothing \\
\dot{\phi} & \varnothing \\
\dot{\phi} & \varnothing \\
\dot{\varnothing} & \varnothing\end{array}$ & $\begin{array}{ll}\dot{\phi} & \varnothing \\
\dot{\phi} & \varnothing \\
\dot{\varnothing} & \dot{\varnothing} \\
\dot{\varnothing} & \dot{\varnothing}\end{array}$ & $\begin{array}{l}\dot{\varnothing} \\
\varnothing \\
\varnothing \\
\varnothing \\
\varnothing\end{array}$ & $\begin{array}{ll}\dot{\varnothing} & \varnothing \\
\dot{\phi} & \varnothing \\
\dot{\varnothing} & \varnothing \\
\dot{\varnothing} & \varnothing\end{array}$ & $\begin{array}{l}\dot{\phi} \\
\dot{\varnothing} \\
\dot{\varnothing} \\
\dot{\varnothing}\end{array}$ \\
\hline
\end{tabular}

Participators: Maloti Rani, Joy Bishwas, Mostafizur Rahman, Md. Tapos, Manna Ali, Laila Banu, Rumman Islam Facilitors: Anutosh Das, Abdus Salam, SK Abu Taher, Rayhanul Islam

Community: South Nilkhet Residential Colony and Nilkhet BCS Staff Quarter

\section{Figure 06: Seasonal Diagram for School Going Children's}

(Source: Field Survey, 2015)

\section{Seasonal Diagram of the school van drivers:}


The seasonal map of school van drivers shows the variation of their activities in different seasons of the year. Seasonal variation occurs in the case of happiness, income, and sickness of the van driver. Van drivers' happiness is varied throughout the year (Figure 07). In January, it is difficult for the van driver to operate the van in the morning due to cold weather. In May and August, it is difficult to maintain the regular operation of the van due to high temperatures and heavy rain. Secondly, the income of the van driver varies from time to time through the year. In April, May, and December, the van drivers were paid without their service because, at that time, the school was either closed or unable to access due to rain. When they are sick from different diseases, it is challenging to operate the van.

\section{SEASONAL ANALYSIS OF SCHOOL VAN DRIVERS}

\begin{tabular}{|c|c|c|c|c|c|c|c|c|c|c|c|c|}
\hline Month & 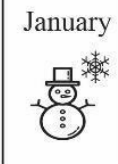 & 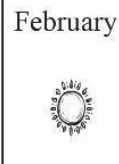 & March & April & May & $\frac{\text { June }}{20}$ & July & August & September & October & 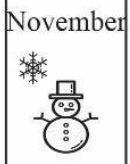 & 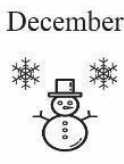 \\
\hline $\begin{array}{l}\frac{\text { Drivers }}{\text { Happiness }} \\
\Phi \Phi \Phi \Phi \Phi \\
\text { Very High } \\
\Phi \text { Very low }\end{array}$ & \begin{tabular}{c}
\multicolumn{1}{|}{$\Phi \Phi$} \\
(Cold winter \\
morning)
\end{tabular} & ФФФФ & ФФФФ & $\begin{array}{l}Ф Ф \Phi Ф \Phi \\
\begin{array}{l}\text { (school } \\
\text { closed) }\end{array}\end{array}$ & $\begin{array}{c}\Phi \Phi \\
\text { (Too hot } \\
\text { days) }\end{array}$ & ФФФФ & ФФ & $\begin{array}{l}\Phi \Phi \Phi \\
\text { (Too much } \\
\text { rain) }\end{array}$ & $\Phi \Phi \Phi$ & ФФФФ & \begin{tabular}{|c|}
\multicolumn{1}{c}{$\Phi \Phi$} \\
(Cold winter \\
morning)
\end{tabular} & $\begin{array}{l}Ф \Phi Ф \Phi \Phi \\
\text { (school } \\
\text { closed) }\end{array}$ \\
\hline Income & $\begin{array}{ll}Q & Q \\
Q & \\
Q & \\
Q & \end{array}$ & $\begin{array}{ll}Q & Q \\
Q & \\
Q & \\
Q & \end{array}$ & $\begin{array}{l}Q \\
Q \\
Q \\
Q\end{array}$ & $\begin{array}{ll}Q & Q \\
Q & Q \\
Q & \\
Q & \end{array}$ & $\begin{array}{l}Q \\
Q \\
Q\end{array}$ & $\begin{array}{ll}Q & Q \\
Q & \\
Q & \\
Q & \end{array}$ & $\begin{array}{l}Q \\
Q \\
Q \\
Q\end{array}$ & $\begin{array}{l}Q \\
Q \\
Q \\
Q\end{array}$ & $\begin{array}{ll}Q & Q \\
Q & \\
Q & \\
Q & \end{array}$ & $\begin{array}{l}Q \\
Q \\
Q \\
Q\end{array}$ & $\begin{array}{l}\mathrm{Q} \\
\mathrm{Q} \\
\mathrm{Q}\end{array}$ & $\begin{array}{ll}Q & Q \\
Q & Q \\
Q & \\
Q & \end{array}$ \\
\hline$\underline{\text { Sickness }}$ & $\begin{array}{ll}\dot{\emptyset} & \quad \\
\dot{\emptyset} & \\
\dot{\phi} & \\
\dot{\varnothing} & \end{array}$ & $\begin{array}{l}\dot{\emptyset} \\
\dot{\emptyset} \\
\dot{\emptyset}\end{array}$ & $\begin{array}{l}\emptyset \\
\varnothing \\
\varnothing ́\end{array}$ & $\begin{array}{l}\dot{\emptyset} \\
\dot{\emptyset} \\
\dot{\emptyset}\end{array}$ & $\begin{array}{l}\dot{\emptyset} \\
\dot{\emptyset} \\
\dot{\emptyset} \\
\dot{\varnothing}\end{array}$ & $\begin{array}{l}\dot{\varnothing} \\
\varnothing \\
\dot{\varnothing}\end{array}$ & $\begin{array}{ll}\dot{\varnothing} & \dot{\varnothing} \\
\varnothing & \\
\dot{\varnothing} & \\
\dot{\varnothing} & \end{array}$ & $\begin{array}{ll}\dot{\varnothing} & \varnothing \\
\dot{\emptyset} & \varnothing \\
\dot{\emptyset} & \\
\dot{\varnothing} & \end{array}$ & $\begin{array}{l}\dot{\varnothing} \\
\dot{\emptyset} \\
\dot{\varnothing} \\
\dot{\varnothing}\end{array}$ & $\begin{array}{l}\dot{\emptyset} \\
\dot{\emptyset} \\
\dot{\emptyset}\end{array}$ & $\begin{array}{l}\dot{\emptyset} \\
\dot{\emptyset} \\
\dot{\emptyset}\end{array}$ & $\begin{array}{ll}\dot{\varnothing} & \dot{\emptyset} \\
\dot{\emptyset} & \varnothing \\
\dot{\varnothing} & \\
\dot{\varnothing} & \end{array}$ \\
\hline
\end{tabular}

Participators: Maloti Rani, Joy Bishwas, Mostafizur Rahman, Md. Tapos, Manna Ali, Laila Banu, Rumman Islam

Facilitors: Anutosh Das, Abdus Salam, SK Abu Taher, Rayhanul Islam

Community: South Nilkhet Residential Colony and Nilkhet BCS Staff Quarter

Figure 07: Seasonal Diagram for Van Driver's

(Source: Field Survey, 2015)

\subsection{Problems associated with van service:}

To identify the existing problems and relative advantages of the van service, a focus group discussion (FGD) was conducted with a group of community people that included eight male and female people. According to the community people, the major driving force of using the van service is advantageous for working parents. Apart from that, the service is environmentally friendly and roads are often dedicated that helps to receive a flexible school transport facility. However, the restraining forces are dominating over the overall advantages. Students' discomfort due to smaller size during traveling, unskilled drivers, slow-moving vehicles, lack of security, faulty van design, and other problems often impede the parents from choosing this transport service (Figure 08). 


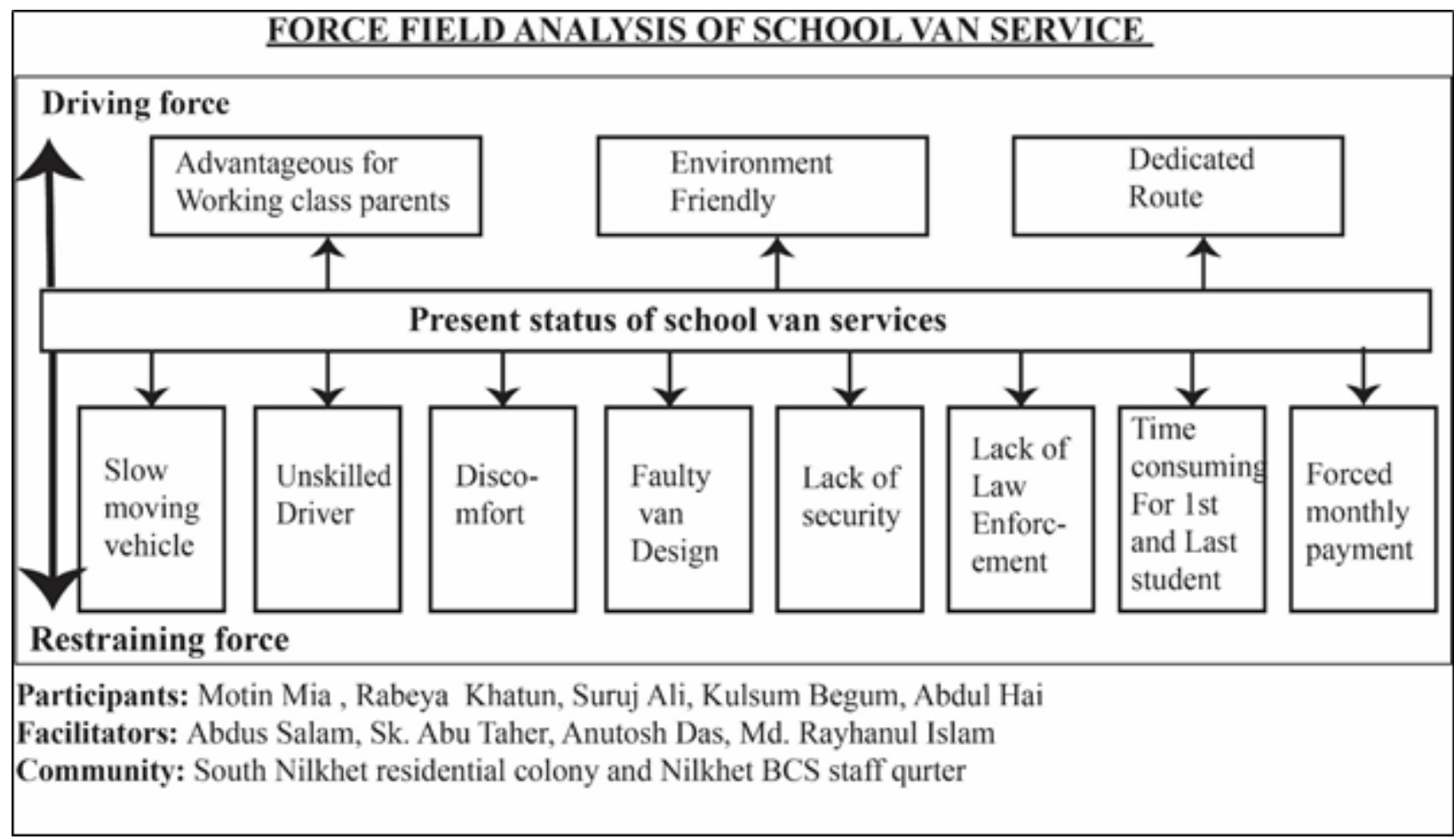

Figure 08: Force Field Analysis of School Van Service

(Source: Field Survey, 2015)

Apart from force field analysis, the pairwise ranking scheme identified one of the major problems as the monthly payment system of school van by the parents. Nevertheless, they do not want to pay extra payments when they do not use the service (during vacation). The inherent causes of this forced monthly payment are lack of other employment opportunities for drivers during the vacation, maintenance, management, and repair of the van, which financially affects the student's family to a large extent. Another major problem is faulty van design. Due to the lack of proper technical knowledge and no regulations on van design, van service often causes discomfort and faces accidents. Getting caught by Weather-related diseases is another worst consequence among the students. Third, the most significant problem was the slow movement of the van. Faulty van design, an excess number of collection points, and bad road conditions often increase the travel time. As a result, students get late to attend their classes.

\section{Findings and Suggestions}

After analyzing the data and discussion, some significant findings have been identified. In most cases, the lower middle to middle-income group is the user of the van service. The level of service seasonally varies greatly. Due to the faulty design structure of the school van, the children suffer most, especially in the rainy season and summer. The van owners are willing to spend more money on the structural improvement of the vans if community people agree to increase the monthly fare. Most van pullers have no means of livelihood other than the van pulling activity. Only two different van owners serve the van service of the Nilkhet Community. Several van drivers work under them and operate school van services. The community identifies forced monthly payments 
that the parents have to pay during school vacation as the first problem of the existing school van service. Faulty van design, unskilled driver, and slow movement are also identified as problems. Because of the lack of students, Van service is used in the study area only for school purposes, not for coaching purposes. The van's routes are selected in accordance with the location of the schools, availability of students, and schedule. There is further scope for enhancing the service for different purposes like shopping, traveling to a picnic place, and as a paratransit service for an aged and disabled person

To identify the solution to the respective problems meeting with community people and van drivers was conducted. During the meeting, some vetting solutions from both parties were discussed and negotiated to come to the same solution. Problem-wise vetting solutions have been listed in Table 02 .

Table 02: Vetting Solutions of the existing problems in school van service

\begin{tabular}{|c|c|c|c|}
\hline Problems & $\begin{array}{l}\text { Community } \\
\text { people }\end{array}$ & $\begin{array}{c}\text { School van service } \\
\text { provider }\end{array}$ & Vetting Solution \\
\hline \multirow{2}{*}{$\begin{array}{l}\text { Forced monthly } \\
\text { payment during } \\
\text { vacation }\end{array}$} & \multirow{2}{*}{$\begin{array}{l}\text { No payment or } \\
\text { concession during } \\
\text { vacation }\end{array}$} & $\begin{array}{l}\text { Increasing monthly } \\
\text { fare }\end{array}$ & \multirow{2}{*}{$\begin{array}{l}\text { Community people need to pay an extra } \\
200 \text { BDT. Per month and van service } \\
\text { provider will not charge the guardian } \\
\text { during vacation. } \\
\text { Local or low-cost materials can be used } \\
\text { to improve the design of the school van. }\end{array}$} \\
\hline & & $\begin{array}{l}\text { Alternative job } \\
\text { opportunity during } \\
\text { vacation }\end{array}$ & \\
\hline \multirow[t]{2}{*}{$\begin{array}{l}\text { Faulty van } \\
\text { design }\end{array}$} & $\begin{array}{l}\text { Prohibition of } \\
\text { overloading }\end{array}$ & $\begin{array}{l}\text { Local or low-cost } \\
\text { materials can be } \\
\text { used to improve the } \\
\text { design of the school } \\
\text { van }\end{array}$ & $\begin{array}{l}\text { Drivers should not carry more than the } \\
\text { capacity of the van. }\end{array}$ \\
\hline & $\begin{array}{l}\text { Improvement of } \\
\text { van design }\end{array}$ & $\begin{array}{l}\text { Introducing training } \\
\text { facility for van } \\
\text { drivers. }\end{array}$ & $\begin{array}{l}\text { The community organization can } \\
\text { introduce a training facility for van } \\
\text { drivers. }\end{array}$ \\
\hline \multirow[t]{2}{*}{ Unskilled driver } & \multirow[t]{2}{*}{$\begin{array}{l}\text { Provisions of a } \\
\text { valid license }\end{array}$} & $\begin{array}{l}\text { Proper monitoring } \\
\text { system by the local } \\
\text { authority. }\end{array}$ & $\begin{array}{l}\text { The proper monitoring system of } \\
\text { providing training and valid local word } \\
\text { commissioner licenses can be useful } \\
\text { solutions. }\end{array}$ \\
\hline & & $\begin{array}{l}\text { Reducing the } \\
\text { number of collection } \\
\text { points }\end{array}$ & $\begin{array}{l}\text { Reducing the number of collection } \\
\text { points. Fixing some collection points } \\
\text { from where they can collect students. }\end{array}$ \\
\hline $\begin{array}{l}\text { Slow-moving } \\
\text { vehicle }\end{array}$ & Dedicated routes & $\begin{array}{l}\text { Fixing some } \\
\text { collection points } \\
\text { from where they can } \\
\text { collect students. }\end{array}$ & $\begin{array}{l}\text { Dedicated routes for every van or fixed } \\
\text { routes for a school can provide an } \\
\text { excellent solution to this problem }\end{array}$ \\
\hline
\end{tabular}




\begin{tabular}{|l|l|l|}
\hline & $\begin{array}{l}\text { Increasing monthly } \\
\text { fare }\end{array}$ & $\begin{array}{l}\text { Community people need to pay an extra } \\
\text { 200 BDT. Per month and van service } \\
\text { provider will not charge the guardian } \\
\text { during vacation. }\end{array}$ \\
\hline
\end{tabular}

(Source: Field Survey, 2015)

The community can solve most of its problems by actively participating appropriately. Based on previous findings, considering the problems and solutions from community people and van service providers, a group of recommendations has been made in the subsequent section.

Formation of a community-based organization for proper operation and maintenance of school van service. This will help to ensure safety for the children, and at the same time, traffic law enforcement will be easier. The respected member of this communityorganization should include community people, elderly persons of the community, van service providers, politically influenced persons, and local ward commissioners. The size of the school van should be appropriate to ensure comfort to the student. Providing fans would be helpful during summer. The design of the van should be compatible with the rainy season. A gutter-like structure may be added to protect the students from drenching because of rainwater. A shed can be used to protect the children from adverse weather. A separate lane should be provided for the school van, which could ease the slow movement of the vehicle.

Specific collecting points can be designated in the community for collecting and dropping the students. These points should be designed with proper facilities like sitting arrangement, Shade etc., for guardians. If the vans are designed to incorporate other trips than school-going purpose to and from the community, that will resolve the problems to some extent. Guardians' extra payment of BDT. Two hundred can be used to improve the van service by improving van design and no payment during school vacation. The target population of the van service is local people. So, in this regard, the local word commissioner can be included in providing training facilities, license of the van driver, and so on. Active school traveling, which means traveling to school by walking under the supervision of community-based organizations, can be introduced as an alternative solution to the existing school van service. This facility is already provided in Ontario, Canada (Cook, 2010).

\section{Conclusion \& Way Forward}

Nowadays, both the population and need for safe and secured transport demand increase in Dhaka City. In such cases, community-based transportation facilities can resolve transportation problems to some extent, thereby reducing the burden on private motorized vehicles. In Dhaka city, different transport policy measures often deal with different transportation problems. But no existing policy measure addresses the necessities of different transportation modes for children and disabled people. In this regard, community-based school van service can play a vital role in solving the problems of short-distance travel in the city territory. Some necessary steps, including the 
intervention of local-level government representatives (ward commissioner) and an active community organization, can be proved efficient to solve the existing problems related to community-based school van service. Through proper management, the implication of the community-based transport service, wings can be spread to address the transport problems for recreational, occupational, and other transport needs of the community people.

\section{References}

Abrol, D., \& Gupta, A. (2015). Understanding the diffusion modes of grassroots innovations in India: A study of Honey Bee Network supported innovators. African Journal of Science Technology Innovation and Development, 541-552. doi:10.1080/20421338.2014.976974

Biswas, R. K., Kabir, E., \& Khan, H. T. (2019). Causes of Urban Migration in Bangladesh:Evidence from the Urban Health Survey. Population Research and Policy Review, 593-614. Retrieved from https://link.springer.com/article/10.1007/s11113-019-09532-3?shared-article-renderer

Boston, C. (2018, June 18). How community-based solutions can improve rural transport in Wales. Retrieved from Wales Center for Public Policy: https://www.wcpp.org.uk/commentary/howcommunity-based-solutions-can-improve-rural-transport-in-wales/

Chambers, R. (1994). Participatory Rural Appraisal (PRA): Analysis of Experience. Pergamon, 22(9), 1253-1268.

Chandra, G. (2010). Participatory Rural Appraisal. In Issues and Tools for Social Science Research in Inland Fisheries (pp. 286-302). Kolkata: Publisher: Central Inland Fisheries Research Institute, Kolkata, India.

Daily Sun. (2021, November 21). Retrieved from https://www.daily-sun.com/post/222748/Transport-abig-hurdle-for-city-children-to-go-to-school-

Hossain, E. A. (2018). The Problems of Public Transport System in Dhaka City. Banglavision, 18(1), 86107. Retrieved from http://bv-f.org/VOL-18/07.\%20BV\%20Final.pdf

Khaled, S. M. (2020, March 17). Traffic gridlock a bane for commuters . Retrieved from The Financial Express: https://thefinancialexpress.com.bd/views/traffic-gridlock-a-bane-for-commuters1584374459

Khan, A. M., \& Mahmud, D. M. (2012). Transport Planning of Dhaka City: Some Contemporary Observations. Retrieved from https://www.academia.edu/5393835/Transport_Planning_of_Dhaka_City_Some_Contemporary_ Observations

Kobra, M. K., Kabir, M. A., \& Biswas, S. K. (2020). COMMUNITY BASED TRANSPORT SYSTEM IN DHAKA: A STUDY ON SCHOOL VAN SERVICE OF AZIMPUR AREA. International Journal of Humanities and Social Sciences (IJHSC), 9(2), 69-76.

Kotecha, M., Davies, M., Miscampbell, G., Barnard, M., \& Hughes, S. (2017). What works: Successful community transport. UK: The Power to Change Trust. 
MTC. (2021). Community-Based Transportation Plans (CBTPs) by Metropolitan Transport Commission (MTC). Retrieved 11 21, 2021, from https://mtc.ca.gov/planning/transportation/access-equitymobility/community-based-transportation-plans-cbtps

Santa Clara Valley Transportation Authority. (2013). Alviso Community-Based Transportation Plan. San Jose,: Santa Clara Valley Transportation Authority. Retrieved from http://files.mtc.ca.gov/pdf/Final_Alviso_CBTP.pdf

Sara, A. M. (2019). Community-Based Transportation and Outdoor Mobility for Older Adults: A Literature Synthesis and Case Study. Canada: SIMON FRASER LIBRARY.

Sharmeen, J., \& Israt, A. S. (2013). MOBILITY AND ACCESSIBILITY PROBLEMS AROUND SCHOOLS IN DHAKA (BANGLADESH): A CASE STUDY. International Journal of Civil Engineering (IJCE), 2(2), 1-8. doi:ISSN 2278-9987

Sontakki, B., Venkatesan, P., \& Rao, V. K. (2019). Participatory Rural Appraisal (PRA), (Tools \& Techniques). ICAR-NAARM, Hyderabad. Retrieved from https://www.researchgate.net/publication/336230869_Participatory_Rural_AppraisalPRATools_ Techniques

The Independent. (2018, July 19). Transport For Students. Retrieved from https://m.theindependentbd.com/magazine/details/158461/Transport-For-Students

Zaman, M. (2019, May 13). Future of Dhaka as a mega city: Lessons from Shanghai-Pudong experience. Retrieved from The Fiancial Express: https://thefinancialexpress.com.bd/views/future-of-dhakaas-a-mega-city-lessons-from-shanghai-pudong-experience-1557328522

Zwart, J., \& Welsby, A. (2006). Community Based Transport System. Queensland: Barbara Dart, Local Government Association of Queensland Inc. Retrieved from file:///C:/Users/awual/Downloads/Pdf_community_based_transport_guidelines\%20(1).pdf 